\title{
Physiologic effects of individual fatty acids in animal and human body, with particular attention to coronary heart disease risk modulation
}

\author{
Dedicated to Prof. Dr. habil. agr. H. Hagemeister on the occasion of his $65^{\text {th }}$ birthday
}

\begin{abstract}
Summary
Dietary fatty acids have a wide spectrum of functions in the body. They may all serve as energy source, but polyunsaturated fatty acids are preferably incorporated into cell membranes and affect membrane composition and functionality. Some fatty acids may change gene transcription, and long chain polyunsaturated fatty acids, released from cell membranes, serve as precursors of eicosanoid synthesis. Fatty acids affect lipid and lipoprotein levels. Lipoproteins may be modified in several ways, e.g. become oxidized or glycated, which in turn affects their metabolic fate. Fatty acids affect endothelial function via inflammatory, oxidative and haemostatic processes. This shows that fatty acids exert regulatory functions in many ways beyond plasma cholesterol level changes. Effects of individual fatty acids are not necessarily one-directional, i.e. there may be both negative and positive aspects to them. Omega3 polyunsatureated fatty acids have a particularly wide spectrum of favourable effects.
\end{abstract}

Key Words: Fatty acids, coronary heart disease, metabolism, diet

\section{Zusammenfassung}

Titel der Arbeit: Physiologische Wirkung spezifischer Fettsäuren im tierischen und menschlichen Organismus, insbesondere im Hinblick auf die Beeinflussung des Risikos koronarer Herzerkrankungen Fettsăuren aus der Nahrung dienen im Körper einer Vielzahl von Funktionen. Sie können als Energielieferanten dienen, aber mehrfach ungesăttigte Fettsăuren werden bevorzugt in die Zellmembranen eingebaut. Sie beeinflussen Membranelastizität und -Funktion. Einige Fettsăuren beeinflussen die Genexpression. Langkettige mehrfach ungesättigfe Fettsäuren dienen, nach der Freisetzung aus den Zellmembranen, als Vorläufer der Eicosanoidsynthese. Fettsäuren beeinflussen die Lipid- und Lipoproteinspiegel. Lipoproteine können Veränderungen erIeiden, z.B. oxidient oder glykosiliert werden, was wiederum ihren Stoffwechsel andert. Fettsäuren beeinfussen die Endothelfunktion aber Entzlndungs-, oxidative und haemostatische Mechanismen. Dies zeigt, daß sie den Stoffwechsel und damit die Gesundheit in vielerlei Hinsicht modulieren. Einzelne Fettsăuren können gleichzeitig positive und negative Wirkungen ausüben. Die mehrfach ungesăttigten $\omega 3$ Fettsăuren haben ein besonders breites Spektrum günstiger Wirkungen.

Schlüsselwơrter: Fettsäuren, Koronare Herzerkrankung, Stoffwechisel, Nahrung

\section{Introduction}

There are some differences in the effect of dietary fat on animal and human metabolism. From the perspective of a human nutritionist the interest in animal metabolism is twofold: for one because animals serve as models of human metabolism and secondly in order to examine whether it is worthwhile to aim at modifying animal fat tissue composition as a food source for humans.

Dietary fat may affect human health in a number of ways, by affecting risk of cancer, 
obesity, diabetes and of coronary heart disease (CHD). CHD and cardiovascular disease in general (heart attack, stroke and peripheral arterial occlusion) are still the leading cause of death in western industrialized countries. The impact of dietary fat on plasma cholesterol levels is but one aspect, and probably not the most important. Though there may be some specific regulatory roles of phospho- and sphingolipids, the major impact is probably exerted via fatty acids.

\section{Definitions}

Fatty acids may be distinguished according to chain length and number, position and stereoisomery of double bonds. Among saturated fatty acids one must distinguish between short chain fatty acids with up to $10 \mathrm{C}$-atoms, those with 12 to $16 \mathrm{C}$-atoms, and stearic acid (18:0). The predominant monounsaturated fatty acid is oleic acid (18:1). Trans fatty acids are mostly monounsaturated fatty acids, i.e. either elaidic acid $(t 9-18: 1)$ or trans-vaccenic acid $(t 11-18: 1)$. There are two groups of polyunsaturated fatty acids, with important differences in metabolic behaviour, i.e. $\omega 6$ and $\omega 3$ polyunsaturated fatty acids. Plant seed oils are particularly rich in linoleic acid (18:2 w6). Some oils, like wheat germ, linseed and canola oil, and the chloroplasts of green leafy vegetables, are sources of $\alpha$-linolenic acid $(18: 3 \omega 3)$. Both linoleic acid and $\alpha$ linolenic acid are present in animal tissues. The longer-chain members of the respective familiy can be synthesized by elongation and introduction of additional double bonds. Arachidonic acid $(20: 4 \omega 6)$ is synthesized from linoleic acid in animals, but not in plants. The longer-chain $\omega 3$ fatty acids, i.e. eicosapentaenoic acid (20:5 $\omega 3)$, and docosahexaenoic acid $(22: 6 \omega 3)$, are mainly found in sea fish. Conjugated linoleic acids (CLA) are another group of fatty acids, but their role is not addressed in this context.

Fatty acids in membranes and further regulatory functions

Dietary fatty acids influence tissue fatty acids. The fatty acid pattern of the adipose tissue is a suitable indicator of long-term fat intake, while plasma fatty acids are a good indicator of the more recent dietary intake (SEIDELIN, 1995). As polyunsaturated fatty acids are essential for membrane functionality, incorporation of polyunsaturated fatty acids into membrane phospholipids is subject to close homeostatic control. Nevertheless, dietary fatty acids do, to a certain degree, modify membrane fatty acid pattern. Different phospholipid classes respond differently, and there is a pronounced organ specificity. Dietary fatty acid pattern does not only affect membrane fatty acid composition, but also lateral organization (lipid domain structure) (CLAMP et al., 1997). Data of AYRE and HULBERT (1996) show that membrane phospholipid fatty acid pattern of rat sceletal muscle is influenced by the dietary fatty acids pattern, that membranes remain enriched in $\omega 6$ polyunsaturated fatty acids even on an essential fatty acid-deficient diet, and that the pattern returns to normal within two weeks after standard diet is resumed (Table 1).

Arachidonic and eicosapentaenoic acid may be released from membrane phospholipids and serve as precursors of eicosanoid synthesis. Their availability affects eicosanoid synthesis. Eicosanoids include prostaglandins, prostacyclins, thromboxanes, leuko- 
Table 1

Fatty acid pattern in experimental diet and in phospholipids of rat muscle depending on dietary fat (Fettsăuremuster der experimentellen Diăten und der Phospholipide im Rattenmuskel nach Verabreichung dieser Diăten)

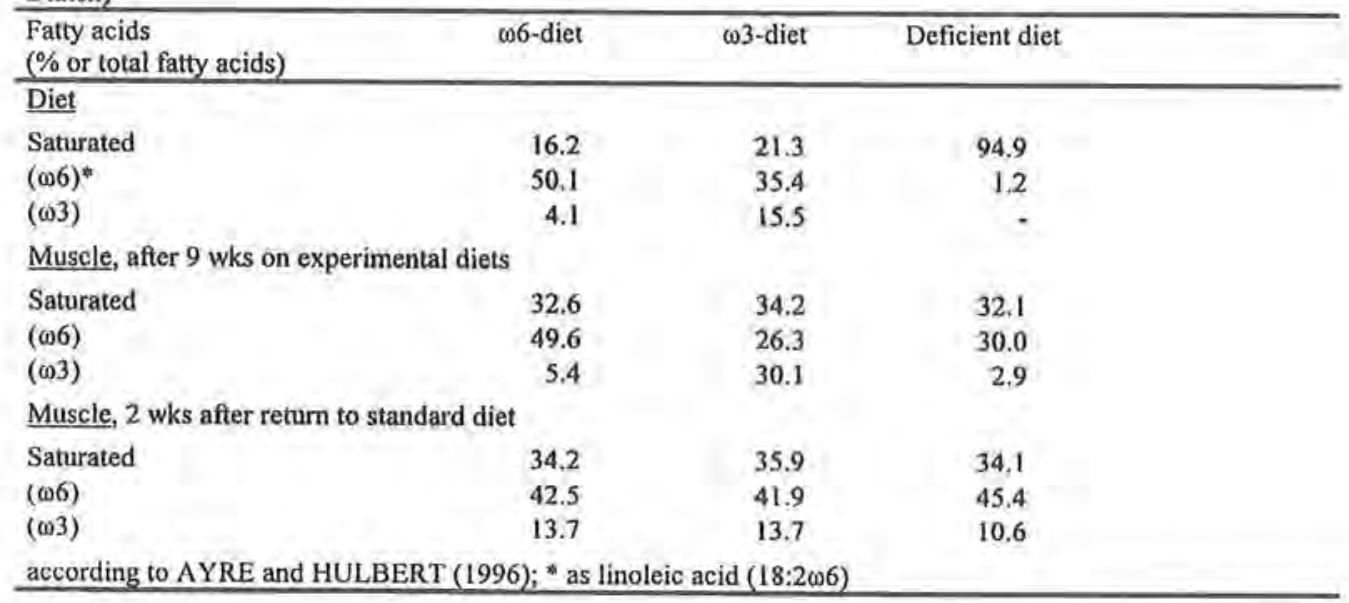

trienes and hydroxy fatty acids. Polyunsaturated fatty acids exert metabolic regulation in another way, i.e. the modification of transcription of specific genes. The capacity of a cell to respond to specific fatty acids will depend on its tissue-specific metabolism, the generation of ligands or second messengers, and the type of nuclear or membrane receptor. Thus, polyunsaturated fatty acids suppress the transcription of a number of genes of lipogenic and glycolytic enzymes in the liver. Furthermore, eicosanoids may leave the cell and regulate gene expression in a paracrine manner (JUMP and CLARKE, 1999; JUMP et al., 1996).

Metabolic events associated with increased CHD risk

This leads up to the question of how different fatty acids may affect CHD risk. Though a heart attack is a sudden event and may occur without previous warning signals, atherosclerotic changes in the vessel walls leading up to this moment took years or rather decades. They start off with the formation of fatty streaks, areas enriched in lipid-laden foam cells. Due to proliferation of cells and connective tissue, plaques develop and increasingly narrow the lumen of the vessels and impair blood flow. Only much later calcium is deposited in the plaques. With plaque growth the vessel loses its elasticity. Platelets are involved in these atherosclerotic changes. A sudden closure of atherosclerotically narrowed and brittle vessels is brought about by severe thrombotic complications, i.e. the formation of thrombi and fibrin clots. Table 2 lists established risk factors, i.e. factors that correlate positively with CHD risk. It is obvious that dietary habits and lifestyle affect all risk factors except age, sex and genetic predisposition. Parameters and mechanisms affecting the progress of atherosclerosis and thrombosis, and how different fatty acids modulate the risk factors and the underlying atherosclerotic and thrombotic events, are listed in table 3.

For a long time high plasma cholesterol levels were seen as a central factor for CHD. It soon became clear that high LDL cholesterol and low HDL cholesterol levels are 
much better risk predictors (CASTELLI et al., 1986). The risk carried by LDL may be explained by the fact that cholesterol-rich LDL are taken up into macrophages via scavenger receptors in an unregulated manner, which turns macrophages into foam cells. One explanation why low HDL cholesterol levels carry an increased CHD risk may be the fact that HDL are involved in the reverse transport of excess cholesterol from tissues to the liver, from where it is eliminated.

Table 2

Established risk factors of coronary heart disease (Risikofaktoren fur Koronare Herzerkrankungen)

- Cholesterol

- HDL Cholesterol

- LDL Cholesterol

- Triglycerides

- Obesity

- High blood pressure

- Smoking

- Diabetes mellitus (Type I and II)

- Genetic predisposition

- Low physical acitivty

- Age

- Male sex

- Low levels of antioxidants (e.g. vitamins E and C)

- Haemostasis factors (platelets, coagulation, fibrinolytic system)

- High homocysteine levels

Table 3

How fatty acids may affect CHD risk by modifying risk factors and further regulatory parameters (Art der Beeinflussung von Risikofaktoren für Koronare Herzerkrankungen und weiterer Regulationsparameter durch Fettsluren)

\begin{tabular}{|c|c|c|}
\hline & negative & positive \\
\hline \multicolumn{3}{|l|}{ Atherogenesis } \\
\hline Cholesterol level & saturated $\mathrm{C} 12-16$, trans & Monoenes, Polyenes \\
\hline (pp) Triglyceride levels & - & all, esp. $\omega 3$-Polyenes \\
\hline ox-LDL & $\omega 6$ - and $\omega 3$-Polyenes & Monoenes \\
\hline Glycated LDL & saturated $\mathrm{C} 12-16$ & Monoenes, Polyenes \\
\hline Leukotrienes (in inflammation) & $\omega 6$-Polyenes & $\omega 3$-Polyenes \\
\hline \multicolumn{3}{|l|}{ Thrombogenesis } \\
\hline Prostacyclins $\leftrightarrow$ Thromboxanes & w6-Polyenes & i3-Polyenes \\
\hline Leukotrienes (in inflammation) & $\omega 6$-Polyenes & w3-Polyenes \\
\hline Haemostasis & $-\quad$ & (1)3-Polyenes \\
\hline - Fibrinogen levels & - & $\omega 3$-Polyenes \\
\hline - Fibrinolysis: $\quad$ PAI etc. & - & $\omega 3$-Polyenes \\
\hline LP (a) & trans & - \\
\hline
\end{tabular}

High fasting triglyceride levels are associated with an increased risk, too, at least in combination with low HDL cholesterol levels. Epidemiological (SHARRETT et al., 1994) and case-contol studies (PATSCH et al., 1992) found also a positive correlation between CHD risk and postprandial (pp) triglyceride levels. The postprandial regulatory principles are as follows: Triglyceride-rich chylomicrons accept cholesterol from HDL, thus reducing HDL cholesterol levels. They give in turn triglycerides to 
HDL and LDL. These triglyceride molecules are quickly removed by the action of lipoprotein lipase (LPL), and thus small, dense LDL and HDL are formed. Small, dense LDL and cholesteryl ester-enriched chylomicron and VLDL remnants, in turn, are only slowly cleared from the blood (ROCHE and GIBNEY, 1995; EBENBICHLER et al,, 1995). Both types of remnants damage endothelial cells, stimulate the adhesion of monocytes to the endothelium, and accumulate in macrophages and intima (CHUNG et al., 1994). At the same time, due to the prolonged circulation in the blood, the postprandial LDL become susceptible to oxidation and glycation. Postprandial LDL accumulate more readily in macrophages than fasting LDL. Higher postprandial triglyceride levels are furthermore associated with higher levels of coagulation factors, which are also independent risk factor for CHD (SALOMAA et al., 1993; ROCHE and GIBNEY, 2000). This scenario shows that high postprandial triglyceride levels may indeed increase both atherosclerotic and thrombotic risk. High HDL cholesterol levels may thus be protective by improving the clearance of postprandial chylomicrons and VLDL.

There is plenty of evidence that oxidative modification of LDL is a critical event in atherogenesis (STEINBERG, I997; AVIRAM, 1993). Oxidized LDL (ox-LDL) may promote atherogenesis in a number of ways. (1) They increase the adhesion of monocytes and leukocytes at the endothelium (2) They facilitate the migration of monocytes into the subendothelial space, their transformation into macrophages, immobilisation, and final transformation into foam cells. (3) Ox-LDL bind firmly to proteoglycans in the subendothelial space and promote the proliferation of connective tissue, as well as of smooth muscle cells. (4) Ox-LDL are cytotoxic and may therefore directly damage endothelial cells, which in turn promotes attachment of monocytes, leukocytes and platelets. Ox-LDL may be generated if LDL are rich in polyunsaturated fatty acids and if the oxidative defense systems are insufficient. Ox-LDL are found in atherosclerotic plaques (YLA-HERTTUALA et al., 1989) and the levels of oxidized lipids in the lipoproteins correlate positively with fatty streak formation in the vessels (STAPRÃNS et al., 1996). In animal models atherosclerosis was prevented by antioxidants like probucol or vitamin E (VERLANGIERE and BUSCH, 1992) and epidemiologic observations suggest that a high intake of vitamin $\mathrm{E}$ is associated with a lower CHD risk (KUSHI et al., 1996). Actually, antioxidants may act in a twofold manner, by preventing LDL oxidation and by stabilizing existing plaques, i.e. by preventing acute thrombotic events. Within this scenario there may be two more protective roles of HDL against CHD, i.e. that HDL protect LDL against oxidation, and that HDL interrupt the adhesion molecule expression cascade (XIA et al., 1999).

There is no evidence that the type of fatty acids in the diet would promote or be responsible for diabetes onset. But lipid metabolism is disturbed both in juvenile (type I) diabetes, and in adult, non-insulin dependent diabetes mellitus (NIDDM, type II). Diabetics show typically high triglyceride and VLDL cholesterol and low HDL cholesterol levels. NIDDM patients have small, dense LDL and HDL particles, similar to those in postprandial plasma. They have also high levels of ox-LDL and, due to hyperglycemia, also atherogenic glyclated LDL (STEWART et al., 1994). Glycation promotes LDL uptake into macrophages (RAVANDI et al. 1999). Epidemiological studies suggest indeed that even moderately increased glucose levels imply a considerably 
increased CHD risk (GERSTEIN and YUSUF, 1996). Frequently there is a combined incidence of disturbed glucose metabolism, disturbed fasting and postprandial lipid metabolism, hypertension and overweight, which is called 'metabolic syndrome' or 'syndrome X'. These combined disorders are part of the explanation why diabetics have a two- to three-fold increased risk of atherosclerosis and CHD compared with the general population.

Besides oxidative processes, inflammation and haemostasis balance affect endothelial integrity and thus risk of atherogenesis and thrombogenesis (DE CATERINA, 2000; MEYDANI, 2000). Eicosanoids may be involved in inflammatory events, Leukotrienes derived from arachidonic acid $(20: 406)$ are proinflammatory and impair the integrity of the endothelium, those derived from eicosapentaenoic acid $(20: 5 \omega 3)$ are of much weaker actiyity or show non activity at all. The balance between prostaglandins and thromboxanes contributes to thrombogenesis. PG $I_{2}$ in endothelial cells, generated from arachidonic acid, is vasodilatory and inhibits platelet adhesion and aggregation, while TX $A_{2}$ in platelets, also generated from arachidonic acid, supports these processes. Ideally, the system is on balance, but the balance may shift, If supply of eicosapentaenoic acid and docosahexaenoic acid is high, the synthesis of TX $\mathrm{A}_{2}$ in the platelets is largely inhibited, while only minor amounts of the weakly active TX $\mathrm{A}_{3}$ are synthesized. But the synthesis of PG $\mathrm{I}_{2}$ in endothelial cells is hardly changed, and active $P G I_{3}$ is generated in addition. This leads to a shift towards a diminished thromotic risk, and would transfer into an advantage of $\omega 3$ over $\omega 6$ polyunsaturated fatty acids. As eicosapentaenoic acid can be synthesized from $\alpha$-linolenic acid, though with moderate efficiency, $\alpha$-linolenic acid is also suited to shift the eicosaonid pattern in a favourable way,

Not only platelet aggregation but also fibrin clot formation contributes to blood vessel occlusion. This means that thrombotic risk is modulated by all factors which affect either fibrin clot formation or dissolution. Omega- 3 fatty acids are the most favourable in this respect. Concomitantly with the decreased postprandial triglyceride levels they decrease the levels of pro-coagulatory factors (ROCHE and GIBNEY, 2000) and promote the dissolution of existing fibrin clots. Furthermore, they lower fibrinogen levels, reduce the viscosity of the blood, improve the fluidity of erythrocyte membranes, and thus blood flow and oxygen supply to the tissues (MEYDANI, 2000). In this context is should be mentioned that insulin resistance in type II diabetes is associated with unfavourable changes of fibrinolysis parameters. Therefore, improvement of the plasma lipid profile of diabetics may reduce CHD via such a mechanism, too.

$\mathrm{Lp}(\mathrm{a})$ is a lipoprotein with atherothrombogenic and pro-coagulatory properties (SCANU, 1998). Lp(a) is a LDL particle with an additional protein, apoprotein(a), which is linked to apoprotein B-100 via a disulfide bridge. Apoprotein (a) shares sequence homologies with plasminogen, and it is assumed that apoprotein(a) competes with plasminogen for binding sites at fibrinogen, thus impairing fibrinolytic activity of the enzyme plasmin. Interestingly, $\mathrm{Lp}(\mathrm{a})$ is not influenced by dietary measures, except that it is increased by trans-fatty acid intake (NESTEL et al, 1992). Therefore, trans fatty acids may increase CHD risk not only via increased plasma cholesterol levels, but via increased $\mathrm{Lp}(\mathrm{a})$ levels, too. 
A $\omega 3$ fatty acid-specific effect is the prevention of cardiac arrhythmia, which occurs as a consequence of atherosclerotic plaques in the coronary arteries, and is responsible for a large number of cardiovascular deaths. Experimentally induced arrhythmia may be lowered by dietary $\omega 6$ and particularly $\omega 3$ fatty acids, but not by saturated or monounsaturated fatty acids (PEPE and McLENNAN, 1996). A case-control study in the USA found that one fish meal per week decreased risk of arrhythmia by $50 \%$ (SISCOVICK et al., 1995). Animal experiments suggest that $\alpha$-linolenic acid has a protective effect in this respect, too.

\section{Effect of fatty acids on risk parameters}

There are numerous studies concerning the impact of dietary fatty acids on plasma and lipoprotein cholesterol and triglyceride levels, with sometimes contradictory outcome. Therefore it is wise to rely on meta-analyses. Data collected by MENSINK and KATAN (1992) conclude that both monounsaturated and polyunsaturated fatty acids decrease total and LDL and increase HDL cholesterol levels. All fatty acids lower fasting triglyceride levels when exchanged for carbohydrates (Fig.). Another metaanalysis (CLARKE et al., 1997) found an even more pronounced hypocholesterolemic effect of polyunsaturated fatty acids with respect to total and LDL cholesterol, but a less pronounced increase of HDL cholesterol. Though not specified by MENSINK and KATAN, there is strong evidence that only saturated fatty acids with 12-16 C-atoms

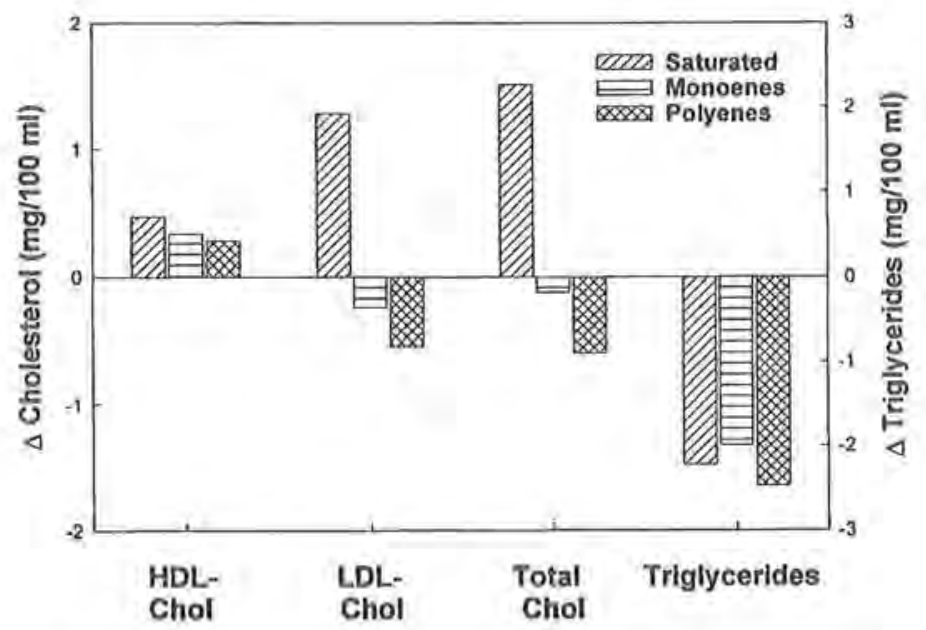

Fig.: Changes of total and lipoprotein lipid levels if $1 \%$ of energy, originally provided by carbohydrates, is given as saturated, monounsaturated or polyunsaturated fatty acids. According to MENSINK and KATAN (1992) (Änderungen der Serum- bzw, Lipoproteinlipidspiegel, wenn 1\% der ursprunglich in Form von Kohlenhydraten (Stärke) zugefuhrten Nahrungsenergie durch gesăttigte, einfach oder mehrfach ungesăttigte Fettsăuren ersetzt wird, nach MENSINK und KATAN (1992))

are hypercholesterolemic, as are trans-fatty acids. Also, $\omega 3$ polyunsaturated fatty acids have a much more pronounced triglyceride-lowering effect than $\omega 6$ polyunsaturated fatty acids. Their effect on cholesterol levels is not different from that of $\omega 6$ polyun- 
saturated fatty acids. It may yet be that the impact of dietary fatty acids is less pronounced under free-living than under strictly controlled experimental conditions.

Postprandial triglyceride levels are less increased by dietary polyunsaturated (BERGERON and HAVEL, 1995) and monounsaturated fatty acids (de BRUIN et al., 1993) than by saturated fatty acids, both in man and experimental animals, though the response to butter fat was similar to that of an oil rich in polyunsaturated fatty acids (SALOMAA et al., 1993). Omega-3 fatty acids attenuated the postprandial triglycerides more than $\omega 6$ fatty acids (ZAMPELAS et al., 1994). There are obviously interactions between dietary carbohydrates and fats in the postprandial state, for addition of fructose (JEPPESEN et al., 1995) increases the response to dietary fat. This means that monounsatured and polyunsaturated fatty acids, particularly $\omega 3$ fatty acids, are suited to improve both cholesterol and triglyceride levels, and other risk factors associated with high cholesterol and triglyceride levels.

From the above described scenario it is obvious that a high intake of both $\omega 6$ and $\omega 3$ polyunsaturated fatty acids might increase the risk of ox-LDL formation. Whether this is so depends on the presence of dietary and endogenous antioxidant systems. Diet provides antioxidants like vitamin $\mathrm{C}$ and $\mathrm{E}, \mathrm{B}$-carotin, flavonoids and selene. There are antioxidants of endogenous origin, like proteins (HDL, albumin, tranferrin, ceruloplasmin, glutathione, urate) and enzymes (glutathione peroxidase, superoxide dismutasc, catalase, paraoxonase). Still, monounsatured fatty acids may be preferable with respect to LDL oxidation risk.

The beneficial role of $\omega 3$ polyunsaturated fatty acids in inflammation and haemostatic control has been mentioned before, as well as the negative effect of trans-fatty acids on Lp(a) levels.

\section{Conclusions}

Even though the above described effects of fatty acids are in part only proven in vitro and in experimental animals, and though there are observations not supporting the conclusions, they are very convincing. In the light of the present knowledge on the role of fatty acids in human and animal metabolism, a scientific committee of the Deutsche Gesellschaft für Ernährung (DGE), Österreichische Gesellschaft für Ernährung (ÖGE), Schweizer Gesellschaft für Ernährung (SGE) and Schweizerische Vereinigung für Ernährung (SVE) recommends for humans a moderate fat intake of not more than $30 \%$ of total energy, of which not more than $10 \%$ should be provided as saturated fatty acids and around 7, but at most $10 \%$ of total energy should be provided as polyunsaturated fatty acids. The ratio of $\omega 6: \omega 3$ fatty acids should be improved to $5: 1$, i.e. in favour of the $\omega 3$ polyunsaturated fatty acids (DGE, ÖGE, SGE, SVE, 2000). Though the longer chain $\omega 3$ polyunsaturated fatty acids are the most effective, an increase in $\alpha$ linolenic acid will also be beneficial and the intake of foods rich in $\alpha$-linolenic acid is encouraged. With this amount of polyunsaturated fatty acids adverse effects are not to be expected (ERITSLAND, 2000). In contrast to some older reports more recent studies have shown that $\omega 3$ fatty acids don't impair glucose homeostasis (ERITSLAND, 2000). Therefore dietary advice to diabetics is the same as for the general population. 
Modified forms of low density lipoprotein and atherosclerosis. Afherosclerosis 98 (1993), 1-9

AYRE, K.J.; HULBERT, A.J.:

Dietary fatty acid profile influences the composition of sceletal muscle phospholipids in rats. J. Nutr. 126 (1996), 653-662

BERGERON, M; HAVEL, R.J.:

Influence of diets rich in saturated and omega-6 polyunsaturated fatty acids on the postprandial response of apolipoproteins B-48, B-100, E, and lipids in triglyceride-rich lipoproteins. Arterioscler. Thromb. Vasc. Biol. 15 (1995), 2111-2121

BRUIN, T.W.A. de; BROUWER, C.B.; LINDE-SIBENIUS TRIP M. van, et al.:

Different postprandial metabolism of olive oil and soybean oil: a possible mechanism of the highdensity lipoprotein conserving effect of olive oil. Am. J, Clin. Nutr. 58 (1993), 477-483

CASTELLI, W.P.; GASSISON, R.J.; WILSON, P.W.F., et al.: Incidence of coronary heart disease and lipoprotein cholesterol levels: The Framingham Study, J.A.M.A. 256 (1986), 2835-2838

CHUNG, B.H.; TALLIS, G.; YALAMOORI, V.; etal.: Liposome-like particles isolated from human atherosclerotic plaques are structurally and compositionally similar to surface remnants of triglyceride-rich lipoproteins. Arterioscler, Thromb. 14 (1994), 622-635

CLAMP, A.G.; LADHA, S.; CLARK, D.C,; GRIMBLE, R.F.; LUND, E.K.:

The influence of dietary lipids on the composition and membrane fluidity of rat hepatocyte plasma membrane. Lipids 32 (1997), 179-184

CLARKE, R, FROST, C.; COLLINS, R. et al.:

Dietary lipids and blood cholesterol: quantitative meta-analysis of metabolic ward studies. B.M.J, 314 (1997), 112-117

DE CATERINA R.:

Endothelial dysfunction: common denominators in vascular disease. Curr. Opin. Lipidol. 11 (2000), 9-23

Deutsche Gesellschaft für Ernăhrung (DGE); Österreichische Gesellschaft für Emährung (ÖGE); Schweizer Gesellschaft fiur Ernährung (SGE); Schweizerische Vereinigung filr Ernahrung (SVE): Referenzwerte für die Năhrwertzufuhr. Umschau Braus Verlag Frankfurt a.M. 2000

EBENBICHLER, C.F.; KIRCHMAIR, R.; EGGER, C.; PATSCH, J.R.: Postprandial state and atherosclerosis. Curr, Opin. Lipidol. 6 (1995), 286-290

ERITSLAND, J.: Safety considerations of polyunsaturated fatty acids. Am. J. Clin. Nutr. 71 (2000), 197S-201S

GERSTEIN, H.C.; YUSUF, S.:

Dysglycaemia and risk of cardiovascular disease. Lancet 347 (1996), 949-950

HOWELL, W.H.; MeNAMARA, D.J.; TOSCA, M.A.; SMITH, B.T.; GAINES, J.A.: Plasma lipid and lipoprotein responses to dietary fat and cholesterol: a meta analysis. Am. J. Clin. Nutr. 65 (1997), 1747-1764

JEPPESEN, J.; CHEN, Y.D.I.; ZHOU, M.Y.; et al.: Effect of variations in oral fat and carbohydrate load on postprandial lipemia. Am. J, Clin. Nutr. 62 (1995), 1201-1205

JUMP, D.B; CLARKE, S.D.:

Regulation of gene expression by dietary fat. Anmu. Rev. Nutr. 19 (1999), 1963-1990

JUMP, D.B.; CLARKE, S.D.; THELEN, A.; et al:

Dietary polyunsaturated fatty acid regulation of gene transcription. Prog. Lipid Res. 35 (1996), 227-241

KUSHI, L.H.; FOLSOM, A.R.; PRINEAS, R.J.; et al.:

Dietary antioxidant vitamins and death from coronary heart disease in postmenopausal women. N. EngL J. Med. 334 (1996), II56-1162

MENSINK, R.P.; KATAN, M.B.: Effect of dietary fatty acids on serum lipids and lipoproteins. Arterioscler. Thromb, 12 (1992), 91 I-919

MEYDANI, M.:

Omega-3 fatty acids alter soluble markers of endothelial function in coronary heart disease paticnts. Nutr. Rev. 58 (2000), 56-59

NESTEL, P.; NOAKES, M.; BELLING, B.; et al::

Plasma lipoprotein lipid and Lp[a] changes with substitution of elaidic acid for oleic acid in the diet. J. Lipid Res. 33 (1992), 1029-1036 
PATSCH, J.R.; MIESENBÖCK, G,; HOPFERWIESER, T.; et al.:

Relation of triglyceride metabolism and coronary artery disease. Arterioscler. Thromb. 12 (1992), 13361345

PEPE, S.; MCLENNAN, P.L.:

Dietary fish oil confers direct antiarrhythmic properties on the myocardium of rats. J. Nutr. 126 (1996), $34-42$

RAVANDI, A; KUKSIS, A.; SHAIKH, N.A.:

Glycated phosphatidylethanolamine promotes macrophage uptake of low density lipoprotein and accumulation of cholesteryl esters and triacylglycerols. J. Biol. Chem. 274 (1999), 16494-16500

ROCHE, H.M.; GIBNEY, M.J.:

Effect of long-chain n-3 polyunsaturated fatty acids on fasting and postprandial triacylglycerol metabolism. Am. J. Clin. Nutr. 71 (2000), 232S-237S

ROCHE, H.M.; GIBNEY, M.J.:

Postprandial triacylglycerolaemia - nutritional implications. Prog. Lipid Res. 34 (1995), 249-266

SALOMAA, V.; RASI, V.; PEKKANEN, J.; ct al:

The effects of saturated fat and n-6 polyunsaturated fat on postprandial lipemia and haemostatic activity. Atherosclerosis 103 (1993), 1-11

SCANU, A.M.:

Atherothrombogenicity of lipoprotein(a): the debate. Am. J. Cardiol, 82 (1998), 26Q-33Q

SEIDELIN, K.N.:

Fatty acid composition of adipose tissue in humans. Implications for the dietary fat-serum cholesterolCHD issue. Prog. Lipid Res. 34 (1995), 199-217

SHARRETT, A.R.; PATSCH, W.; SORLIE, P.D,; et al.:

Association of lipoprotein cholesterols, apolipoprotein A-1 and B, and triglycerides with carotid atherosclerosis and coronary heart disease. Arterioscler. Thromb, 14 (1994), 1098-1104

SISCOVICK, D.; RAGHUNATHAN, T.E.; KING, I; et al.:

Dietary intake and cell membrane levels of long chain n-3 fatty acids and the risk of primary cardiac arrest. J.A.M.A. 274 (1995), 1363-1367

STEINBERG, D.:

Low density lipoprotein oxidation and its pathological significance. J. Biol. Chem. 272 (1997), 2096320966

STEWART, M.W.; LAKER, M.F.; ALBERT, K.G.M.M.:

The contribution of lipids to coronary heart disease in diabetes mellitus. J. Int. Med, 236 (Suppl) (1994), $41-46$

STAPRÃNS, I; RAPP, J,H; PAN, X.M,; et al.:

Oxidized lipids in the diet accelerate the development of fatty streaks in cholesterol-fed rabbits. Arterioscler. Thromb. Vasc. Biol. 16 (1996), 533-538

VERLANGIERE, A.J.; BUSH, M.J.:

Effects of $\alpha$-tocopherol supplementation on experimentally induced primate atherosclerosis. J. Am. Coll. Nutr, 11 (1992), 131-138

XIA, P.; VADAS, A.; RYE, K.A.; BARTER, P.J.; GAMBLE, J.R.;

High density lipoproteins (HDL) interrupt the sphingosine kinase signaling pathway, J. Biol, Chem. 274 (1999), 33143-33147

YLA-HERTTUALA, S.; PALINSKI, W;; ROSENFELD, M.; et al::

Evidence for the presence of oxidatively modified low density lipoprotein in atherosclerotic lesions of rabbit and man. J. Clin. Invest. 84 (1989), 1086-1095

ZAMPELAS, A.; MURPHY, M.; MORGAN, L.M.; WILLIAMS, C.M.:

Postprandial lipoprotein lipase, insulin and gastric inhibitory polypeptide responses to test meals of different fatty acid composition: comparison of saturated, $n-6$ and $n-3$ polyunsaturated fatty acids. Eur. J, Clin. Nutr. 48 (1994), 849-458

Received: $2000-10-18$

Accepted: 2000-11-08

Author's address

Dr. MARIA PFEUFFER, Department of Physiology and Biochemistry of Nutrition,

Federal Dairy Research Centre,

P. O. Box 6069

D-24113 Kiel / Germany

E-Mail: pfenffer@bafim.de 